\title{
The Efficiency and Effectiveness of capital expenditure in the Province of South Sulawesi
}

\author{
Sahade \\ Pendidikan Akuntansi, Fakultas Ekonomi, Universitas Negeri Makassar \\ Email: sahade@unm.ac.id
}

(Received: December 12-2019; revised: February 15-2020; published: June 31-2020)

\begin{abstract}
This study aims to describe the efficiency and effectiveness of capital expenditure in the Province of South Sulawesi. To study this problem, ex post facto research is used. The data type uses secondary data for 2009-2013 time brackets. Data collection techniques using study documentation. Based on the results of the study found that the amount of indirect expenditure still dominates the regional expenditure allocation. While indirect spending is consumptive, while direct expenditure tends to be both short-term and long-term investment. Based on the results of the analysis during 2009-2013 which uses the consumption approach rather than the production approach. But this approach produces growth, but it is short-term and volatile. Overall, based on the profile of expenditure allocation, it can be said that the implementation has not been carried out efficiently and effectively. In the future, it is expected that the Regional Government of South Sulawesi Province can increase the allocation of direct expenditure so that there is a balance with indirect spending, so that conditions in the long run are very beneficial because it increases the overall welfare of the community quickly and sustainably.
\end{abstract}

Keywords: Capital Expenditure; Consumption; Capital; growth

\section{INTRODUCTION}

Capital expenditure is the costs incurred for the purchase of capital goods used in carrying out government activities, including the purchase of land, the purchase of machinery and equipment, construction of buildings, roads, installations, networks and other fixed assets (Khan, 2019). Capital expenditures undertaken by local governments will affect regional economic growth. In addition, capital expenditure will also be a leverage in driving the wheels of the regional economy (Aulya et al., 2016; Dincă, 2019; Quinton, 2018; Rampersad, 2013; Schnellenbach \& Schubert, 2015).

Based on PP No. 71 of 2010 concerning Government Accounting Standards for capital expenditures including capital expenditures for the acquisition of land, buildings and buildings, equipment and intangible assets. Furthermore, it is explained in the Government Regulation that what is meant by fixed assets are tangible assets that have a useful life of more than 12 months to be used in government activities or utilized by the general public (Isma et al., 2017; Niswaty et al., 2016; S. Saggaf et al., 2014; Salam \& Rosdiana, 2015).

Remembering this, planning and controlling capital expenditure is an important activity that must be carried out by regional governments, because spending that is carried out without good planning and in its implementation is not well controlled will also be a source of inefficiency and waste of regional finances (Pratiwi et al., 2019). This will certainly have an impact on the loss of society in general and small communities in particular who will feel the 
direct impact of development and economic growth. Conversely, if capital expenditure is managed in an economical, efficient and effective manner it will have a good impact on people's welfare. The principle in budgeting is Economical, Efficiency and Effectiveness (value for money) is one of the applications of good governance. So that local governments can carry out these principles, then an understanding of the concept of spending is very important. By understanding the concept of expenditure, planning and controlling capital expenditure will be easier to do.

Conceptually, in regional expenditure there are two different sides but they are closely related, namely the expenditure policy and expenditure management. The regional expenditure policy is related to the determination of "what will be done" by the regional government, while the regional expenditure management is related to "how to implement expenditure" to finance government activities so that it can be done economically, efficiently and effectively. Regional expenditure policy is carried out at the planning stage and expenditure management is carried out at the implementation stage. Usually spending policies are more political and spending management is technical. Shopping policies will affect shopping management, and basically shopping management will adjust to shopping policies(Pratiwi et al., 2019; M. S. Saggaf et al., 2017).

In the implementation of expenditure, the available funds must be utilized as well as possible to be able to produce maximum service and welfare improvement in order to improve and meet the interests of the community. Therefore, in budget planning, attention should be given to setting goals and objectives, results and benefits, setting priorities, and setting rational unit prices.

Based on imprint data on expenditure budgeted by the South Sulawesi provincial government in 2007 amounting to Rp. 338,457,682,430, - with the realization of Rp. $321,0884,680,925$ or $94.56 \%$ of the target. Total capital expenditure of total expenditure is $17.24 \%$. If calculated from total revenue, capital expenditure spent by local governments is 17.74\%. Whereas in 2008 the total budgeted capital expenditure was Rp. 302,432,998,692, with the realization of a budget of Rp. $275,180,935,215$ or $90.98 \%$. Meanwhile, total capital expenditure was $12.89 \%$ of total regional expenditure. Meanwhile, if compared to 2007 this number actually decreased, both for absolute and relative values.

The data above shows the value that is not in accordance with the needs of the public, but in meeting the budget allocation there are no rules on how much capital expenditure should be allocated by local governments in each fiscal year, but given the main objectives of regional autonomy and fiscal decentralization in which regions given the authority to manage their own households, so that it becomes a big challenge for local governments to relocate budgets for productive spending by creating an efficient bureaucracy and being able to provide good quality public services.

Based on the above background, the formulation of the problem in this study is "Has the capital expenditure spent by the regional government of South Sulawesi Province been carried out efficiently and effectively?". 


\section{METHOD}

This type of research is an Ex Post Facto descriptive study. This descriptive research is considered suitable so that research can examine the phenomenon in more depth and broadly with what is happening and developing in the social situation under study. The locus of this research is the regional government of South Sulawesi Province. Source of data used in this study are primary data and secondary data. Primary data are officials who are deemed to have competence in the area of regional finance, especially those related to regional planning, namely the APBD General Policy, Priority and Budget Ceiling, Local Government Work Plans (RKPD), and Regional Medium-Term Development Plans (RPJMD). In addition to primary data, it also uses secondary data, namely in the form of South Sulawesi Provincial Government Financial Reports, BPS data, other relevant sources. The time period used consists of time series data for five years, from 2009 to 2013. The use of time series data so that the study is more guaranteed accuracy. The data used is collected in various ways, namely; observations, interviews and documentation. Observation technique is carried out by tracing data sources about the elements that form the basis of capital expenditure planning and allocation. Interview technique, namely by conducting interviews with key informants working in the area of regional finance and having competence which is the problem of this research.

The focus of this research is the efficiency and effectiveness of the regional government capital expenditure in South Sulawesi Province. The capital expenditure budget referred to is fixed assets that are classified based on similarities in nature or function in the entity's operating activities. The fixed assets are classified as follows; a) land; b) equipment and machinery; c) buildings and buildings; d) roads, irrigation, and networks; e) other fixed assets; and f) construction in progress. The data analysis technique used in this study is the technique of financial analysis. The use of financial analysis is considered more appropriate to interpret the figures of local government financial statements so as to provide certain meanings that are useful for decision making. The financial analysis technique is intended to be analysis of variance, analysis of operating expenditure ratios, capital expenditure, tentative expenditure, and transfers to total expenditure, ratio of direct and indirect expenditure to total expenditure, and growth in spending. Then the financial ratios are analyzed descriptively (Creswell \& Creswell, 2017).

\section{RESULT AND DISCUSSION}

To realize economical, efficient and effective regional financial management, the Regional Government of South Sulawesi Province should apply the principles of regional expenditure management in a careful, consistent and sustainable manner. Optimization of regional financial management must pay attention to 2 aspects namely revenue and expenditure, but regional expenditure management needs to receive considerable attention from revenue management. Based on this, even though the focus of the study was regional expenditure, it would not be wrong if it still presented a picture of the size of the South Sulawesi Province's revenue budget in the 2009-2013 time period.

In terms of budget implementation, there may be differences between regional income and expenditure, the causes can be very diverse, but the regional surpluses and deficits that arise 
206 Jurnal Ilmiah Ilmu Administrasi Publik: Jurnal Pemikiran dan Penelitian Administrasi Publik Volume 10 Number 1, January - June 2020. Page 203-212

naturally must be addressed by the regions with regional financing policies. The magnitude of the revenue and realization budget of South Sulawesi Province over the 2009-2013 time period is shown in Figure 1.

\section{Target, Realization of revenue}

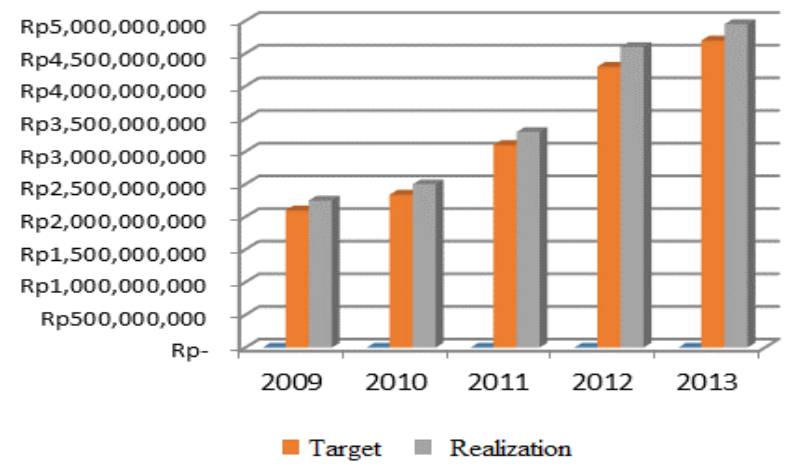

Earnings Achievement

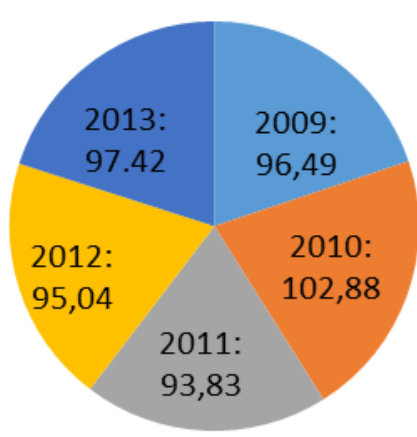

Source: Financial Report in South Sulawesi Province

Figure 1

Targets, Realization and Achievement of Revenue in the Province of South Sulawesi in 2009-2013

Based on Figure 1, it appears that the realization of South Sulawesi Province's revenue in the period of 5 years (2009-2013) averaged 97.13\%. The highest achievement was achieved in 2010 at $102.88 \%$ and the lowest in 2011 at $93.83 \%$. Even though the achievement has not reached 100\%, the income growth aspect of the Province of South Sulawesi can be said to be good. Furthermore, data on the presentation of South Sulawesi Province's revenue growth in the 2009-2013 period are shown in Figure 2.

\section{Revenue Growth}

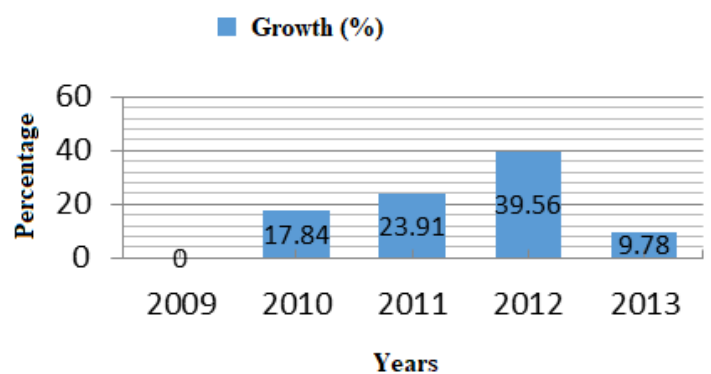

\section{Shopping Targets and Realization}

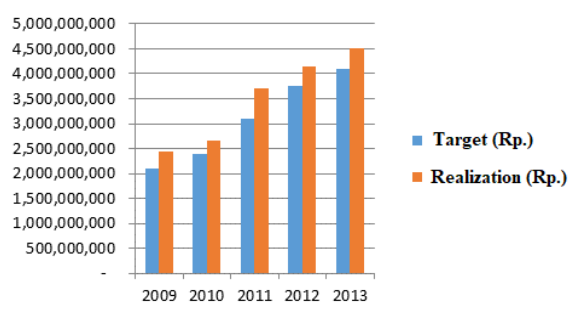

Source: Financial Report in South Sulawesi Province

Figure 2

Revenue Growth, Targets and Realization of South Sulawesi Province Expenditures Year 2009-2013 
Figure 2 presented the average growth achieved at $18.22 \%$ per year and tends to increase from 2009 to 2012. However, in 2013 the growth achieved was only $1 / 4$ less than the growth in 2012. If in 2012 the growth achieved was $39.56 \%$, in 2013 it only reached $9.78 \%$.

Optimization of regional finances in addition to paying attention to aspects of income, aspects of expenditure should be a major focus of attention, because in certain conditions saving expenditure is more difficult than obtaining it. Whereas the average regional expenditure achieved in South Sulawesi Province within a period of 5 years, namely 2009-2013 was $91.73 \%$. It also appears that the realization of spending from year to year tends to increase, but in 2013 according. For more details, can be seen in Figure 3.

Shopping Realization

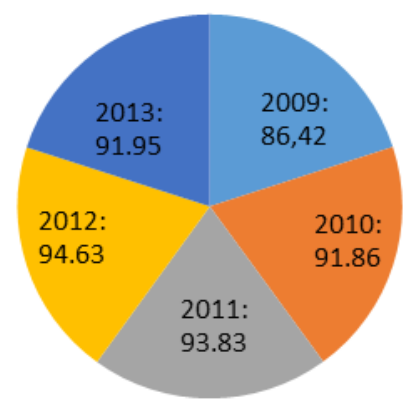

Shopping Growth

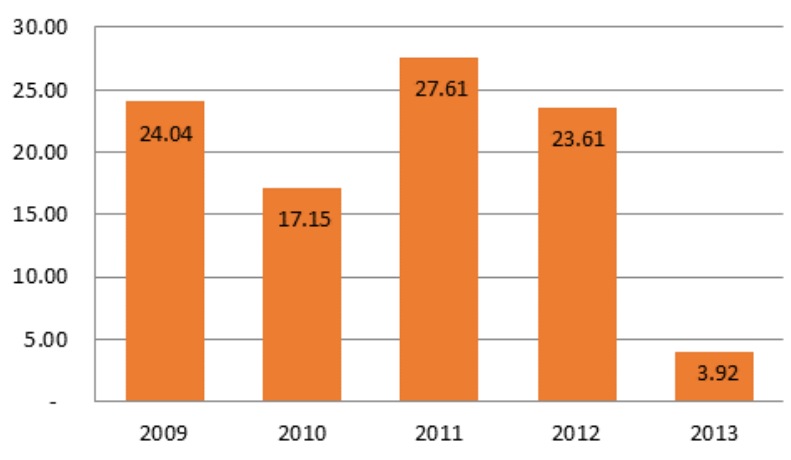

Source: Financial Report in South Sulawesi Province

Figure 3

Realization and Growth of South Sulawesi Province Expenditure in 2009-2013.

Based on figure 3, the average regional expenditure achieved in South Sulawesi Province in the 2009-2013 time frame was $91.73 \%$. It also appears that the realization of spending from year to year tends to increase, but in 2013 according. In the era of regional autonomy, local governments must be able to control regional spending, improve expenditure efficiency and save budget. South Sulawesi Province expenditure growth experienced extreme evidence. If in 2009 the growth reached $24.07 \%$, in 2010 it only increased by $17.15 \%$ compared to 2009 , but in 2011 it increased dramatically by about $27.61 \%$ compared to 2010 . After that, the growth actually decreased to $23.61 \%$ and in 2013 experienced a very sharp decline of only $3.92 \%$.

Based on Government regulation No. 24 of 2005 concerning Government Accounting Standards as previously explained in the format of capital expenditure, tentative spending and transfers. The magnitude of each classification of the expenditure budget in South Sulawesi Province for a period of 5 years from 2009-2013.

In general, shopping has a tendency to always go up. The reasons for the increase are usually associated with inflation, changes in the rupiah exchange rate, changes in the scope of public services to be carried out by the government, and adjustments to macroeconomic factors. It appears that the portion of regional expenditure for operating expenditure dominates at an 
208 Jurnal Ilmiah Ilmu Administrasi Publik: Jurnal Pemikiran dan Penelitian Administrasi Publik

Volume 10 Number 1, January - June 2020. Page 203-212

average of $72.32 \%$ in the period 2009-2013. Operational expenditure is expenditure whose benefits are consumed in one budget, so operational expenditure is short-term in nature and in certain cases it is routine or recurring.

Capital expenditure is expenditure allocated for investment in the relevant fiscal year. In contrast to investment spending in the fiscal year concerned. In contrast to short-term and routine operational expenditure, capital expenditure provides medium-term and long-term benefits and is not routine. In the period 2009-2013 the average capital expenditure of South Sulawesi Province was $11.80 \%$. Capital expenditure will affect the regional government balance sheet, which will add to the regional assets.

Transfer or commonly referred to as profit sharing expenditure and financial assistance, is revenue sharing for regional income determined by law. In the period 2009-2013 the average transfer expenditure of the South Sulawesi Provincial Government was $15.83 \%$. This financial assistance expenditure is given to regencies / cities or villages in the area of South Sulawesi Province.

To find out the growth of each expenditure classification, it can be explained that each type of expenditure growth fluctuates, the most extreme growth is unexpected expenditure. While operating expenditure growth is prominent, namely in 2012 amounting to 58.09\%, while in 2013 it decreased dramatically only growth of $1.07 \%$. Likewise, the highest growth in capital expenditure in 2011 was $54.02 \%$, whereas in 2010 it was only $2.63 \%$. In 2012 the growth decreased to reach $19.36 \%$ and in 2013 it increased again to $29.98 \%$. The average growth transfer is $19.46 \%$ per year.

In addition to the analysis of classification based on the time period enjoyed for these expenditures, namely operating expenditure, capital expenditure, tentative expenditure and transfers carried out, the analysis needs to be done on the classification based on activities, namely direct expenditure and indirect expenditure. This analysis is needed in the interests of local government internal management, namely for cost control and budgetary control (cost and budgetary control). For the period 2009-2013 the classification of direct and indirect expenditure is explained that the regional government expenditure in South Sulawesi province is dominated by indirect expenditure. The average expenditure in the 2009-2013 period was $65.80 \%$, while at the same time the average direct expenditure was $34.20 \%$. Direct expenditure should be greater than indirect expenditure, because direct expenditure will strongly affect the quality of activity output.

The analysis will be continued with growth analysis to determine the growth of the two types of expenditure. It can be explained that: 1) Direct average growth in the period of 20092013 was $18.47 \%$ and 2) Indirect expenditure average growth in the 2009 period -2013 at $30.51 \%$. Growth in direct expenditure (BL) is only about $60 \%$ of indirect expenditure (BTL), while direct expenditure (BL) largely determines the quality of activity output. Direct expenditure is capital expenditure and goods / services which constitute investment. In terms of macroeconomics, employee expenditure and other expenditure is called leakage, while capital expenditure is an investment injection. The growth of these two expenditures is also very volatile. 


\section{Discussion}

Since the enactment of the Regional Autonomy Law, the implementation of government tasks in regional development including public services has been funded by the Regional Budget. Therefore, the Regional Revenue and Expenditure Budget is one of the drivers of economic growth in the region. The Regional Income and Expenditure Expectation can also be said as a trigger and determinant of the achievement of macroeconomic targets and targets of an area. The targets and targets made by a local government are directed to overcome the various problems and obstacles found in efforts to improve the welfare of the community.

South Sulawesi Province is one of the provinces outside of Java where revenue realization over a period of 5 years namely 2009-2013 averaged $97.13 \%$. His achievement can be said to be less good, because his income should be greater than the target. Whereas the average income growth achieved by $18.82 \%$ per year and tends to increase from year to year. This achievement is a good achievement. However, it is necessary to do an analysis of the calculation of income potential, this potential does not have to be realized entirely in one fiscal year but can be done in stages up to several fiscal years (Fox et al., 2002; Freire-González, 2018).

Planning an income budget is an important thing that must first be done by the government before determining the size of the expenditure budget, this has been regulated in the statutory provisions that every expenditure budgeted must be supported by the certainty of the availability of revenue in sufficient amounts (Adie, 2019; Khan, 2019; Wong, 2006). Revenue planning to determine the level of financial capacity of the government in providing public services, implementing budget allocation and distribution policies, as well as determining budget surplus / deficit policies, and determining the direction of budget financing policies.

To realize economical, efficient and effective regional financial management, regional expenditure management must be oriented to realize three things, namely growth, equity and economic stability. To maintain economic stability, regional expenditure management must be focused on implementing budgetary discipline. Meanwhile, to achieve economic growth and equity, expenditure management must focus on the efficiency and effectiveness of budget allocations in various development activities programs. For this reason, the main objective of expenditure management is to ensure fiscal discipline through expenditure control, the allocation must be in accordance with policies and priorities and guaranteed budgeting planning principles, namely economic, efficiency and effectiveness. Based on the expenditure profile in general, it can be said that regional expenditure allocation has not been done economically, efficiently and effectively.

\section{CONCLUSION}

The results of the analysis carried out, it can be concluded that the profile of regional expenditure allocation from the South Sulawesi government for 5 years namely 2009-2013, namely: 1) Aspect of the target and the realization is quite good, the achievements, the achievements achieved an average of $91.73 \%$, meaning that the realization Local government expenditure $\leq$ a specified budget. The variance or difference that occurs is favorauble variance or preferred, 2) Aspects of growth in expenditure, regional expenditure tends to increase on 
average growth by $18.11 \%$ per year, this is considered to be relatively good, 3) Aspect of expenditure based on benefit, is dominated by ie operating expenses, by an average of $72.32 \%$. While capital expenditure is only $11.80 \%$ whereas capital expenditure is an investment for the long term, 4) aspects of the classification of expenditure based on activity, which is dominated by indirect expenditure which is in line with operating expenditure which is an average of $65.80 \%$ per year. While direct expenditure is only about one-half of indirect expenditure, namely an average of $34.20 \%$ per year, and 5) aspects of expenditure growth, both based on the classification of benefits and activities tend to fluctuate extreme, but the average is good. Based on the general expenditure profile it can be said that the allocation of regional expenditure has not been done economically, efficiently and effectively.

\section{REFERENCES}

Adie, P. G. K. (2019). Capital Budgeting Analysis to Assess the Karaoke Business Feasibility. PINISI Discretion Review, 3(1), 47-52.

Aulya, R., Mindarti, L. I., \& Amin, F. (2016). Strengthening Local Economy Through Community-Based Tourism in Governance Perspective (Study at Sidomulyo Tourism Village, Batu City). Jurnal Ad'ministrare, 3(2), 11-30.

Creswell, J. W., \& Creswell, J. D. (2017). Research design: Qualitative, quantitative, and mixed methods approaches. Sage publications.

Dincă, V. (2019). Determinants of cloud computing adoption by romanian smes in the digital economy. Journal of Business Economics and Management, 20(4), 798-820. https://doi.org/10.3846/jbem.2019.9856

Fox, T., Ward, H., \& Howard, B. (2002). Public Sector Roles In Strengthening Corporate Social Responsibility: A Baseline Study Strengthening Corporate Social Responsibility: A Baseline Study. The World Bank.

Freire-González, J. (2018). Environmental taxation and the double dividend hypothesis in CGE modelling literature: A critical review. Journal of Policy Modeling, 40(1), 194-223. https://doi.org/10.1016/j.jpolmod.2017.11.002

Isma, E. W., Darwis, M., Saleh, S., \& Salam, R. (2017). Kualitas Pelayanan Administrasi pada Puskesmas Gattareng Kecamatan Gantarang Kabupaten Bulukumba. JURNAL ILMU ADMINISTRASI PERKANTORAN (JIAP), 21-28.

Khan, A. (2019). Capital Budgeting and Improvement Process. In Fundamentals of Public Budgeting and Finance (pp. 275-318). Springer.

Niswaty, R., Darwis, M., Alimuddin, W., \& Salam, R. (2016). Pengaruh Penerapan Prinsip Good Governance terhadap Efektivitas Kerja Pegawai. Jurnal Ilmiah Administrasi Publik (JIAP), 95-100.

Pratiwi, N. J., Jamaluddin, J., Niswaty, R., \& Salam, R. (2019). The Influence of Work Facilities on Employee Performance at the Regional Financial Management Agency Secretariat Section of South Sulawesi Province. Jurnal Ad'ministrare, 6(1), 35-44.

Quinton, S. (2018). Conceptualising a digital orientation: antecedents of supporting SME performance in the digital economy. Journal of Strategic Marketing, 26(5), 427-439. 
https://doi.org/10.1080/0965254X.2016.1258004

Rampersad, G. (2013). Innovation in the digital economy: The impact of high-speed broadband on innovating SMEs. In Proceedings of the 24th Australasian Conference on Information Systems.

https://www.scopus.com/inward/record.uri?partnerID=HzOxMe3b\&scp=84923924843\&o rigin=inward

Saggaf, M. S., Salam, R., \& Rifka, R. (2017). The Effect of Classroom Management on Student Learning Outcomes. International Conference on Education, Science, Art and Technology, 98-102.

Saggaf, S., Salam, R., Kahar, F., \& Akib, H. (2014). Pelayanan Fungsi Administrasi Perkantoran Modern. Jurnal Ad'ministrare, 1(1), 20-27.

Salam, R., \& Rosdiana. (2015). Penerapan Fungsi Administrasi Perkantoran Modern berbasis Daya Saing Organisasi dalam menyongsong MEA 2015. SEMINAR NASIONAL "Revolusi Mental Dan Kemandirian Bangsa Melalui Pendidikan Ilmu-Ilmu Sosial Dalam Menghadapi MEA 2015” Himpunan Sarjana Pendidikan Ilmu-Ilmu Sosial Indonesia, 1, 186-190.

Schnellenbach, J., \& Schubert, C. (2015). Behavioral political economy: A survey. European Journal of Political Economy, 40, 395-417. https://doi.org/https://doi.org/10.1016/j.ejpoleco.2015.05.002

Wong, K. L. (2006). Financial management. In Professional Housing Management Practices in Hong Kong. https://doi.org/10.5005/jp/books/10677_12 
212 urnal Ilmiah Ilmu Administrasi Publik: Jurnal Pemikiran dan Penelitian Administrasi Publik Volume 10 Number 1, January - June 2020. Page 203-212 